\section{JAVNE FINANCIJE}

\section{Aktualni osvrti}

Institut za javne financije $•$ Katančićeva $5 \cdot 10000$ Zagreb

Tel. (+385 1) 4886-444, Fax. (+385 1) 4819-365

www.ijf.hr•ured@ijf.hr

Br. 3

Zagreb, 27. lipnja 2008.

\title{
Hrvatski porezni uspjeh
}

\section{mr. sc. Marina Kesner-Škreb}

Hrvatska je najbolji reformator u Europi. Početkom mjeseca lipnja Hrvatskoj je dodijeljena nagrada Svjetske banke za najboljeg reformatora u Europi i drugog u svijetu. Nagrada je dobivena na temelju vrlo sveobuhvatnog istraživanja pod nazivom «Doing Business 2008» koji Svjetska banka provodi od 2004. godine i koje iz godine u godinu privlači sve više medijske pažnje. Ove godine Svjetska banka provela je istraživanje u 178 zemlje, a Hrvatska je u toj velikoj i šarenoj skupni zemalja zauzela 97 mjesto. U odnosu na 2007. godinu učinjen je pomak od 23 mjesta. Pozitivan pomak učinjen je u osam od deset kriterija koje promatra Svjetska banka. Jedan od najvećih pomaka doživio je kriterij nazvan plaćanje poreza i pomaknuo se u odnosu na 2007. za 12 mjesta. Upravo zato ovaj kriterij zaslužuje malo više pažnje.

Hrvatska je treća u regiji po kriteriju plaćanja poreza. Hrvatska se u skupini od 28 zemalja iz regije zemalja Istočne Europe i Središnje Azije, po uspješnosti plaćanja poreza nalazi na trećem mjestu odmah iza Latvije i Estonije. Iza nje su zemlje poput Češke, Poljske, Mađarske i Slovačke koje su već davno svladale brojne tranzicijske tegobe.

Mjerenje plaćanja poreza. Da bi izmjerila koliko se uspješno plaćaju porezi, Svjetska banka koristi tri pokazatelja: 1. broj uplata pojedinačnih poreza koje poduzetnik treba napraviti, 2. vrijeme mjereno satima koje je provedeno u pripremi podataka, ispunjavanu poreznih prijava i plaćanju poreza, i 3. udio ukupnih poreza u dobiti poduzeća koje poduzetnik mora platiti državi. Sudeći prema sva tri pokazatelja Hrvatska je bolja u odnosu na prosjek regije, a prema ukupnoj poreznoj stopi čak je i bolja od zemalja OECD-a. 


\begin{tabular}{|l|c|c|c|}
\hline \multicolumn{1}{|c|}{ Pokazatelj } & Hrvatska & $\begin{array}{c}\text { Istočna Europa i } \\
\text { Središnja Azija }\end{array}$ & OECD \\
\hline 1. Broj uplata & 28 & 46,3 & 15,1 \\
\hline 2. Provedeno vrijeme (sati) & 196 & 451,5 & 183,3 \\
\hline 3. Ukupna porezna stopa (\%) & 32,5 & 50,8 & 46,2 \\
\hline Porez na dobit (\%) & 11,4 & 11,2 & 20,0 \\
\hline Doprinosi (\%) & 19,4 & 28,7 & 22,8 \\
\hline Ostali porezi (\%) & 1,7 & 10,8 & 3,4 \\
\hline
\end{tabular}

Izvor: «Doing Business 2008», dostupno na: http://www.doingbusiness.org/

1. Broj uplata. U Hrvatskoj poduzetnici godišnje 28 puta uplate razne poreze državi. To se odnosi na uplate PDV-a, poreza na dobit, doprinosa i raznih manjih poreza. Iako smo po broju uplata dvostruko bolji od zemalja regije još uvijek smo upola gori od zemalja OECD-a. Tako ima još prostora za poboljšanje iako se u odnosu na 2007. godinu broj uplata smanjio s 39 na 28.

2. Provedeno vrijeme. U Hrvatskoj poduzetnici provedu godišnje 196 sati pripremajući potrebne podatke, ispunjavajući porezne prijave i plaćajući poreze. Po tom smo pokazatelju opet više od dvostruko bolji od zemalja regije i gotovo jednako dobri kao poduzetnici u zemljama OECD-a. Vrijeme koje su poduzetnici proveli baveći se porezima jednako je kao i 2007. godine, pa prema ovom pokazatelju u Hrvatskoj nije učinjen nikakav napredak.

3. Ukupna porezna stopa. Ova stopa uključuje sve poreze koje poduzeća plaćaju, te pored poreza na dobit uključuje i doprinose, poreze na promet, poreze na tvrtku i sl. Izražava se postotkom svih navedenih poreza u poslovnoj dobiti poduzeća. S obzirom da uključuje sve poreze, ovaj je pokazatelj mnogo slikovitiji i potpuniji u prikazivanju porezne opterećenosti poduzeća od njezinog mjerenja isključivo opterećenjem porezom na dobit. $U$ tom je segmentu, s najnižom stopom, Hrvatska u odnosu na zemlje regije, ali i zemlje OECD-a u vidnoj prednosti. Tako ukupna porezna stopa u Hrvatskoj iznosi 32,5\%, što je čak 18,3 postotna boda niže od zemalja regije i 13,7 postotna boda niže od zemalja OECD-a. 


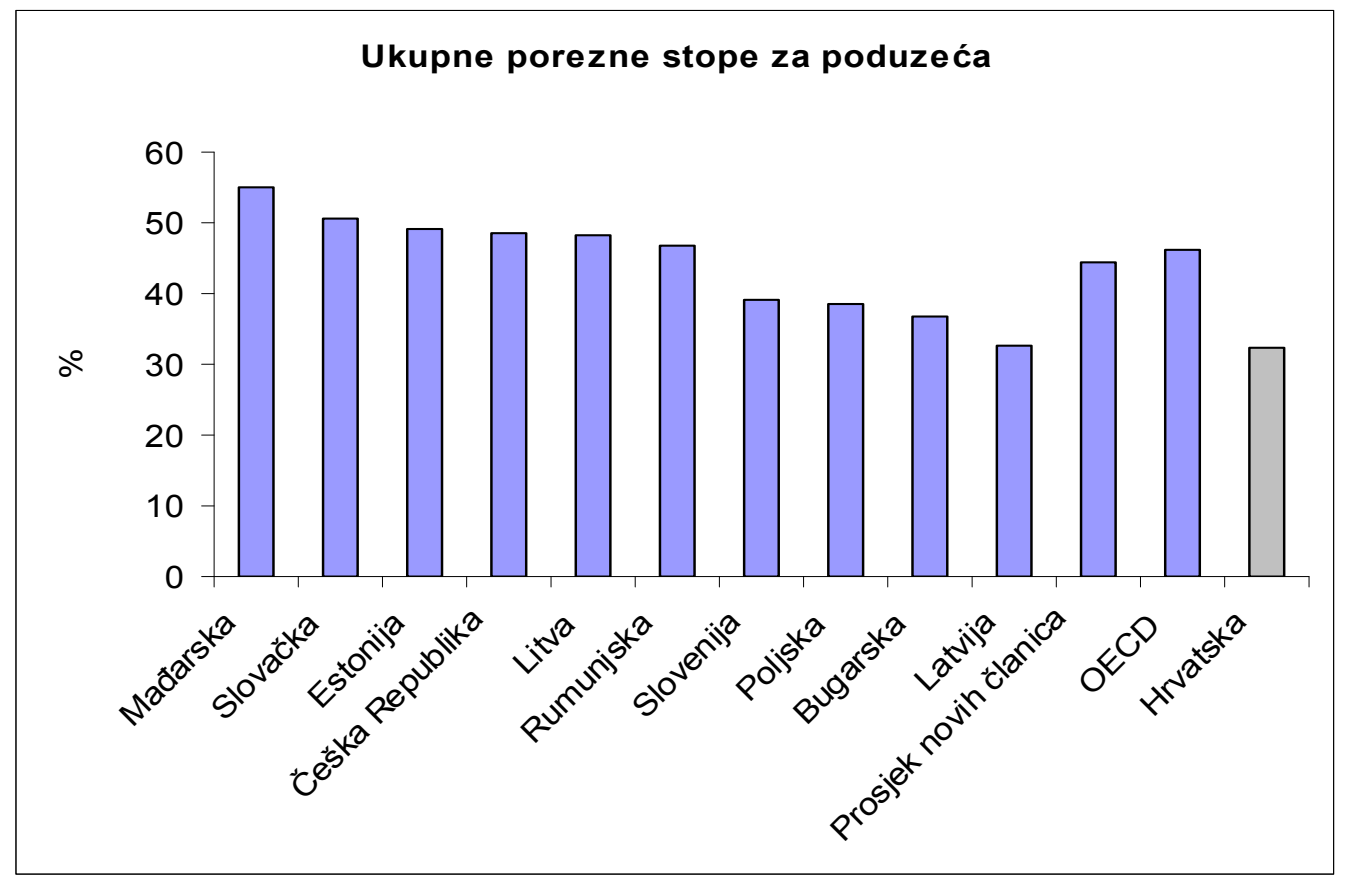

Izvor: «Doing Business 2008», dostupno na: http://www.doingbusiness.org/

Problem hrvatske konkurentnosti nisu porezi. Na gornjoj slici izdvojili smo ukupne porezne stope za nove članice EU-a. U odnosu na njih Hrvatska također bilježi vidan uspjeh te predstavlja najkonkurentniju zemlju u odnosu na sve novopridružene zemlje Uniji. Dok je ukupno porezno opterećenje dobiti u novim članicama u prosjeku 44,5\%, u Hrvatskoj je ono za otprilike četvrtinu niže i iznosi $32,5 \%$. Ako je suditi po podacima ovog istraživanja problem hrvatske konkurentnosti nikako ne leži u području ukupnog poreznog opterećenja poduzeća.

Ima li prostora za daljnje reforme? Istraživanje naglašava kako su porezne reforme uvijek kontraverzne i povezane s burnim političkim raspravama. Obično se smatra da niže porezne stope donose više glasova na izborima, pa se svi napori usmjeravaju na stope. U stvarnosti to ne mora biti tako jer se porezne reforme mogu odvijati na niz područja. Analizom 90 reformi koje su u razdoblju nakon 2005. godine poduzete u 65 zemalja, Svjetska banka zaključuje kako su se najuspješnije reforme odnosile na slijedeće mjere: uvođenje elektroničke prijave poreza, objedinjavanje poreza kojima je ista porezna osnovica, pojednostavljenje procedura u poreznoj upravi, te konačno snižavanje poreznih stopa i širenje porezne osnovice. Zato se državama predlaže da svoje reformske napore usmjere na smanjivanje broja poreza, te na pojednostavljenje i povećanje transparentnosti poreznog sustava kako bi obračun i naplata poreza bili što jednostavniji, a porezna evazija što niža. To bi dakako mogao biti i putokaz budućim poboljšanjima hrvatskog poreznog sustava. 